\title{
C, H, O, S, Pb Isotope Geochemistry and the Implications of Qixiashan Pb-Zn-Ag Polymetallic Deposit in Jiangsu Province
}

\author{
Mingchao Zhang \\ Faculty of Earth Sciences and Resources, China \\ University of Geosciences, \\ Technical Guidance for Mineral Resources Exploration, \\ MLR \\ Beijing, China \\ chris.zhang0210@gmail.com \\ Yongsheng Li \\ Technical Guidance for Mineral Resources Exploration, \\ MLR \\ Beijing, China \\ liysh1983@126.com
}

\author{
Xiaofei $\mathrm{Yu}$ \\ Technical Guidance for Mineral Resources Exploration, \\ MLR \\ Beijing, China \\ xfyu@jlu.edu.cn
}

\author{
Wenbin Jia \\ Faculty of Earth Sciences and Resources, China \\ University of Geosciences, \\ Technical Guidance for Mineral Resources Exploration, \\ MLR \\ Beijing, China \\ Dearjwb@163.com
}

\begin{abstract}
Qixiashan Pb-Zn-Ag polymetallic deposit in Jiangsu Province is located in the Yangtze continental blockthe Lower Yangtze block zone-central of the Lower Yangtze foreland basin, and is a large polymetallic deposit dominated by $\mathrm{Pb}$ and $\mathrm{Zn}$. We have carried out the $\mathrm{C}$ and $\mathrm{O}$ isotope tests of calcite at the main mineralization stage, $\mathrm{H}$ and $\mathrm{O}$ isotope tests of quartz at the main mineralization stage, as well as $\mathrm{S}$ and $\mathrm{Pb}$ isotope analyses and testing of typical sulfide ores in the deposit. The results showed that the $\delta^{13} C_{V-P D B}=-$ $1 \%$ 1.2\%, $\delta^{18} \mathrm{O}_{\mathrm{V} \text {-SMow }}=14.1 \%$ 21.6\%o of calcite in limestones, $\delta^{13} C_{\mathrm{V}-\mathrm{PDB}}=-4.9 \%$ 1.9\%o, $\delta^{18} \mathrm{O}_{\mathrm{V}-\mathrm{SMOW}}=9.1 \%$ 19.6\%o of calcite in ores. This indicates that carbon largely derived from magma at the main mineralization stage of the deposit, and part of the carbon might come from dissolution of marine carbonate. Quart at main mineralization stage showed $\delta \mathrm{D}=-$ $81.8 \%$ \% $-67 \%$ and $\delta^{18} \mathrm{O}=-0.38 \%$ \% $6.25 \%$, indicating that oreforming fluid was mainly magmatic water. And with the progress of mineralization, the mineralization feature of magmatic and meteoric water mixing was revealed. Sulfur isotope ranged in a narrow area from $-4.4 \%$ to $3.6 \%$ at the main mineralization stage, showing that the main source of sulfur was the magma, and mixed with sedimentary sulfur from the surrounding rocks. The test results for $\mathrm{Pb}$ isotopes at main mineralization stage were ${ }^{206} \mathrm{~Pb} /{ }^{204} \mathrm{~Pb}=17.62 \sim 17.82$, ${ }^{207} \mathrm{~Pb} /{ }^{204} \mathrm{~Pb}=15.51 \sim 15.72,{ }^{208} \mathrm{~Pb} /{ }^{204} \mathrm{~Pb}=37.91 \sim 38.59$, indicating the lead was not from a single source of the crust or mantle, and it should be a combination of lead from the upper mantle and the crust brought by magmatic activities.
\end{abstract}

Keywords- isotope geochemistry; source of ore-forming materials; Pb-Zn-Ag polymetallic deposit; Qixiashan; Nanjing

\section{INTRODUCTION}

Qixiashan $\mathrm{Pb}-\mathrm{Zn}-\mathrm{Ag}$ polymetallic deposit in Jiangsu Province is located in $19 \mathrm{~km}$ to the eastern outskirts of Nanjing, Jiangsu Province, and is the only large lead-zinc polymetallic deposit in Ningzhen, and an important part of the Ningzhen ore concentration area in the Yangtze River metallogenic belt. Since Qixiashan deposit was found, a lot of scholars have done a large quantity of research work at the place, including geochemistry of mineral deposits, rock deposits and mineralogy, fluid inclusions, and the provenance of diagenetic and minerogenic substances. There are four main perspectives about the genesis of the deposit: deep source magmatic hydrothermal metallogeny, volcanic or subvolcanic hydrothermal metallogeny, syngenetic sedimentary origin, and strataboundhydrothermal polygenetic cause. After investigation and comprehensive research in recent decades, scholars have generally agreed that the deposit was a hydrothermal deposit, but so far have not found mine rocks, so the source of ore-forming hydrothermal has become the major focus of debate. At present, there are mainly two viewpoints for this problem: 1) magmatic hydrothermal fluid dominated, including post-magmatic hydrothermal fluid as the main part accompanied with meteoric water activities [1], post-magmatic hydrothermal fluid as the main part with the addition of seepage of underground hydrothermal brine [2], and mixed ore-bearing hydrothermal fluids with dominated magmatic hydrothermal fluid etc. [3]; 2) non-magmatic hydrothermal fluids dominated, including precipitation [4], deep circulation hydrothermal percolation and double circulation hot brine $[5,6]$. Therefore, this article has 
planned to carry out $\mathrm{C}, \mathrm{H}, \mathrm{O}, \mathrm{S}, \mathrm{Pb}$ isotope analyses and determination of typical ore minerals in Qixiashan $\mathrm{Pb}-\mathrm{Zn}$ $\mathrm{Ag}$ polymetallic deposit, and combine with the results of previous studies to discusses the sources of the oreforming material and provide a scientific basis for further study of the genesis of mineral deposit and looking for this type of deposits in the region.

\section{GeOLOGICAL}

Qixiashan $\mathrm{Pb}-\mathrm{Zn}-\mathrm{Ag}$ polymetallic deposit in Jiangsu Province located in the Yangtze continental block-the Lower Yangtze block zone - central of the Lower Yangtze foreland basin and it is adjacent to the Qinling-qilianshankunlun orogenic system in the North West and the WuyiYunkai-Taiwan orogenic system in the south east [7]. The deposit located in the west of Ningzhen fault bundle which belongs to the fault depression belt in the lower Yangtze region, and it is adjacent to the Yangtze River fault in the north and the Ningwu volcanic basin in the west.

The stratas from Silurian series to Jurassic series exposed in mining area, and the host stratas are the stratas from upper Devonian series to lower Permian series. A Huanglong formation carbonate stratum of middle Carboniferous is the main host strata. As can be seen from Fig. 1, fold structure in mining area can be divided into upper structure and lower structure, and they are high angular unconformity. Faults in mining area can be divided into three types: NEE longitudinal fault type, NW transverse fracture type and faulted fracture unconformity type and so on. The NEE longitudinal fault which is composed by the deep Fault $\mathrm{F}_{2}$ is the main Ore-controlling fault, and the NW transverse fracture and faulted fracture unconformity are the Secondary Ore-controlling fault. Intrusive rocks do not expose in mining area. Only quartz diorite rock distributed in Chalukou and Yaohuamen area which is in the southwest of mining area, and dioritic porphyrite dike can be found on the suface of Ganjiagang Ore section and in some individual deep drilling holes. Volcanic rocks of Jurassic series exposed in the north of mining area which are a set of sedimentary volcaniclastic rocks sandwiched andesite. The $\mathrm{K}-\mathrm{Ar}$ ages of quartz diorite dikes and volcanic rocks on the surface in the mining area are 119 134Ma [8]. There are weak magnetic anomalies in Xiangshan sandstone distribution area of Qixiashan by aeromagnetic datas. Accordingly, some researchers conjectured that there is a deep source concealed rock mass under the Daaoshan Mountain [2].

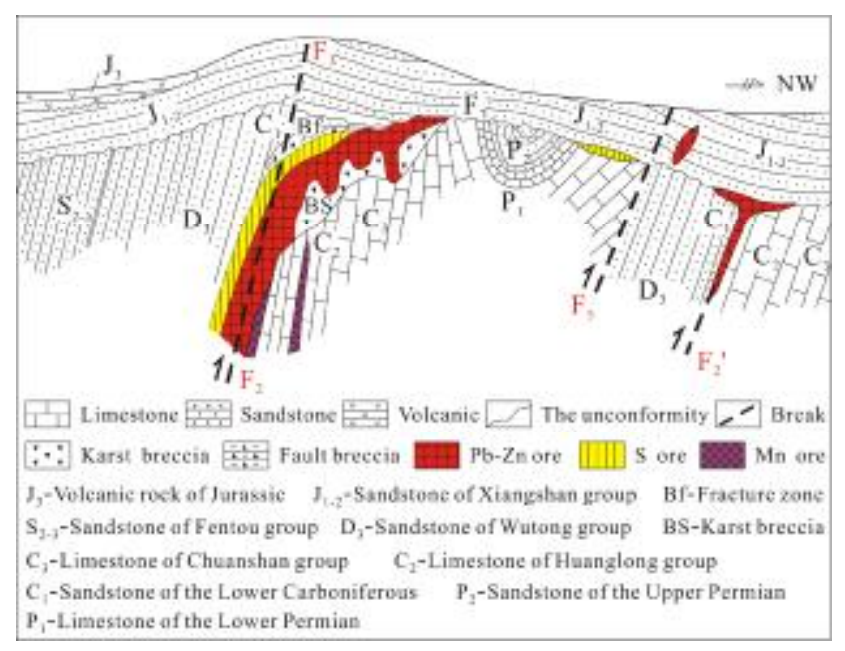

Figure 1. The sketch section map of Qixiashan deposit

Ore bodies mainly were controlled by the fault $\left(\mathrm{F}_{2}\right)$ and the formation (Carboniferous and Permian series-based), and they were distributed by stratiform-like and irregular shapes (cystic, vein and layered). There are nearly 70 ore bodies in the mining area in which the main ore bodies are six. The strike of main ore bodies is about $50^{\circ} \mathrm{NE}$, and it has a "reoccur" feature. The ore bodies extend nearly $5000 \mathrm{~m}$ intermittence, and the thickness of ore bodies are meters to tens meters. Galena, sphalerite and pyrite are the main ore minerals, and rhodochrosite, chalcopyrite and magnetite are the minor ore minerals; quartz and calcite are the main gangue minerals, and barite, sericite and chlorite are the minor gangue minerals. The main ore textures are granular texture, mosaic texture, metasomatic texture and microscopic crushing texture, the minor ore textures are droplet-like textures, and microscopic includes textures, etching textures and skeleton crysral textures and so on. Brecciated structures, massive structures, disseminated are the main structures, and vein structure, net vein banding structure and dispersion banding structure are the minor structures. In addition, laminated structure, jelly crumple structure, miarolitic structure, relict structure and comb structure are hardly found. Brecciated ore, massive ore and disseminated ore are the main natural ore types. Ore industry type can be divided into lead, zinc, sulfur type, single sulfur type and single manganese type. According to the occurrence characteristics, ore types, components of mineral, wall rock alterations and vein intercalating relationships, the mineralization and alteration epochs can be divided into the three phases: synsedimentary hydrothermal phase, hydrothermal mineralization phase and hypergene mineralization phase. The hydrothermal mineralization phase is the main phase for sulphdes of lead, zinc to form, and galena, sphalerite, pyrite, chalcopyrite, tetrahedrite, Au-Ag minerals, and a little of hematite and siderite all formed in this phase.

\section{FEATURES OF ISOTOPE GEOCHEMISTRY}

\section{A. $C$ and $O$ isotopes}

The 11 pieces of calcite samples for $\mathrm{C}$ and $\mathrm{O}$ isotopic studies were taken from limestones and ores in the deep drilling of Tiger Claw mountain mine segment and the underground tunnel of $-625 \mathrm{~m}$. The specific features of $\mathrm{C}$ and $\mathrm{O}$ isotopes in Calcite are listed below, in calcite of 
limestones $\delta^{13} \mathrm{C}_{\mathrm{V}-\mathrm{PDB}}=-1 \%$ \% $1.2 \%$, with the mean value of $0.1 \%$, and $\delta^{18} \mathrm{O}_{\mathrm{V}-\mathrm{SMOW}}=14.1 \%$ o $21.6 \%$, with the mean value of $17.25 \%$; in calcite of minerals $\delta^{13} \mathrm{C}_{\mathrm{V}-\mathrm{PDB}}=-$ $4.9 \%$ o $1.9 \%$, with a mean of $-1.5 \%$, and $\delta^{18} \mathrm{O}_{\mathrm{V}}$. smow $=9.1 \%$ o $19.6 \%$, with a mean of $14.35 \%$. Overall, calcite in Qixiashan deposit showed $\delta^{13} \mathrm{C}_{\mathrm{V}-\mathrm{PDB}}=-$ $4.9 \%$ \% $1.9 \%$, averaged $-1.5 \%, \delta^{18} \mathrm{O}_{\mathrm{V} \text {-SMOW }}=9.1 \%$ \% $21.6 \%$, averaged $15.35 \%$.

Carbon and Oxygen isotopic composition of hydrothermal calcite is an effective means of tracing the source of fluid [9]. There are three main sources of carbon in ore-forming hydrothermal systems: 1) deep source of carbon from the mantle and magma, whose $\delta^{13} \mathrm{C}_{\mathrm{V}-\mathrm{PDB}}$ are in the range of $-5 \%$ o $-2 \%$ and $-9 \%$ - $-3 \%$ respectively [10]; 2) carbon from decarbonization of marine carbonates, with $\delta^{13} \mathrm{C}_{\mathrm{V}-\mathrm{PDB}}$ values most stable near $0 \%$ and the general range of $-4 \%$ \% $4 \%$ [11]; 3) organic carbon, whose $\delta^{13} \mathrm{C}_{\mathrm{V}}$. PDB value changes from $-30 \%$ to $-15 \%$, with an average of $-22 \%$ [12]. The investigation of the source of carbon in hydrothermal deposits also must be based on the total carbon isotopic composition of the mineralization hydrothermal fluid. Under normal circumstances, the carbon isotopic composition of calcite is not equal to the total carbon isotopic composition of the mineralization hydrothermal fluid. Only when there is no graphite in symbiosis with calcite in deposits, the carbon isotopic composition of calcite can be approximately seen as the total carbon isotopic composition of the mineralization hydrothermal fluid. Because no graphite was found in Qixiashan deposit, the carbon isotopic composition of calcite can be approximately seen as the total carbon isotopic composition of the mineralization hydrothermal fluid. Combination with carbonate $\delta^{18} \mathrm{O}_{\mathrm{V} \text {-SMOW }}$ and $\delta^{13} \mathrm{C}_{\mathrm{V} \text { - }}$ PDB composition relationship diagram, as can be seen from Fig.2, we can learn that the ore carbon and oxygen isotope values mainly falls in the zone of granite and the transition zone of granite and marine carbonates, and was nearly in horizontal distribution overall.



Figure 2. $\quad \delta^{18} \mathrm{O}_{\mathrm{SMOW}}$ versus $\delta^{13} \mathrm{C}_{\mathrm{PDB}}$ diagram of the Qixiashan deposit $[13,14,15]$

This form of nearly horizontal distribution of carbon and oxygen isotopes may be caused by two reasons [1517]: 1) degassing of $\mathrm{CO}_{2}$; 2) fluid-rock reactions between the fluid and wall rocks. If the distribution form of carbon and oxygen isotopes is caused by $\mathrm{CO}_{2}$ degassing, considering hydrothermal fluids are generally dominated by $\mathrm{H}_{2} \mathrm{O}$, the effect of $\mathrm{CO}_{2}$ degassing on the oxygen isotopic composition of the fluid is not obvious, while the impact on the carbon isotopic composition is significant [18]. The calcite formed in this case should also have a significant change in the carbon isotope composition. Obviously, this is inconsistent with the actual situation in the study area. Also under the microscope there was no sign of boiling fluid inclusions, and only $\mathrm{CO}_{2}$-bearing three phase's inclusions were observed locally. Therefore $\mathrm{CO}_{2}$ degassing was unlikely the main factor to affect the precipitation of calcite and other carbonate minerals. In the hydrothermal fluid, calcite solubility increases with decreasing temperature, and decreases with decreasing pressure [19]. Cooling in a closed system simply can't make calcite precipitated from hydrothermal fluids, so the precipitation of calcite should be caused by the coupling effect of fluid-rock interaction and the temperature decrease in the mining area [15]. Therefore, the fluid in hydrothermal calcite, which initially originated from the granite, gradually reacted with the wall rocks by fluidrock (especially carbonate rocks) exchange reaction through migration process This not only caused the gradually increase of $\delta^{18} \mathrm{O}$ values in hydrothermal fluid and no significant change of $\delta^{13} \mathrm{C}$, but also promoted the precipitation of hydrothermal calcite.

\section{B. $H$ and $O$ isotopes}

The 9 quartz samples for $\mathrm{H}$ and $\mathrm{O}$ isotope research used in this study were collected from the mineralization related quartz veins in the mine area. Quart at main mineralization stage showed $\delta \mathrm{D}=-81.8 \%$ - $67 \%$ and $\delta 18 \mathrm{O}=-0.38 \% \sim 6.25 \%$. We can see from Fig. 3 , the hydrogen and oxygen isotopes diagram, hydrogen and oxygen isotopes values of quartz in the ores are basically projected to the zone of normal magmatic water and the left side, which is the transition zone of magmatic and meteoric water. We have inferred that the ore-forming fluids are mainly magmatic water, with the addition of a small amount of atmospheric precipitation. The evident described above indicated that the fluids of Qixiashan deposit were mainly from magmatic water, and showed the features of magmatic water mixing with meteoric water to form the ores with the progress of mineralization, and also the proportion of atmospheric precipitation participated in mineralization increased, indicating the deposit was a typical magmatic hydrothermal deposit [20].



Figure 3. $\delta \mathrm{D}-\delta^{18} \mathrm{O}$ diagram of fluid inclusions of the Qixiashan deposit[21,22] 


\section{S isotope}

The $\mathrm{S}$ isotope tests of single mineral have been carried out. The results showed the $\delta^{34} \mathrm{~S}$ values of galena and sphalerite were more concentrated, ranging from $-4.6 \%$ to $3.8 \%$, with an average of $-0.4 \% 0 ; \delta^{34} \mathrm{~S}$ values of pyrite changed in a larger range of $-27.4 \%$ \% $6.9 \%$. According to the structure, construction and ore mineral assemblages, the pyrite in the mine area could be divided into two different causes of pyrite as hydrothermal pyrite and pyrite with deposition characteristics [5]. This $\delta^{34} \mathrm{~S}$ test of hydrothermal pyrite ranged from $-4.4 \%$ o to $3.6 \%$, with an average of $-0.2 \%, \delta^{34} \mathrm{~S}$ values of pyrite with sedimentary characteristics varied from $-27.4 \% \sim 6.9 \%$, with an average of $-10.6 \%$, and a larger negative value $(-27.4 \%)$. The $\delta^{34} \mathrm{~S}$ values of the late metasomatic pyrite (veins), disseminated pyrite and xenomorphic pyrite were similar with that of galena and sphalerite. The change was in accord with symmetrical tower distribution, with the features of meteorite sulfur, as can be seen from Fig.4.

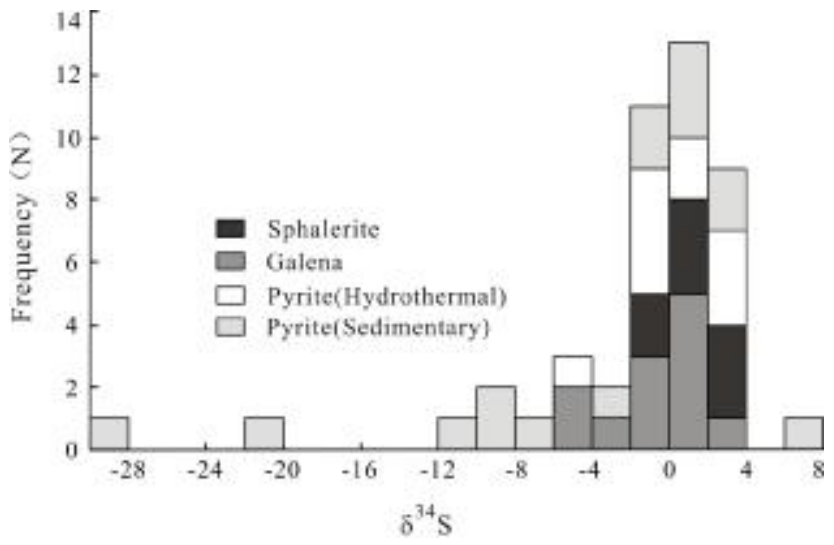

Figure 4. Frequency histogram of $\delta^{34} \mathrm{~S}$ for ore sulfides from the Qixiashan deposit

\section{Pb isotope}

The $17 \mathrm{~Pb}$ isotope analyses of galena and pyrite showed sulfide of lead zinc ore in Qixiashan had the $\mathrm{Pb}$ isotope composition of ${ }^{206} \mathrm{~Pb} /{ }^{204} \mathrm{~Pb}=17.62 \sim 17.82$, ${ }^{207} \mathrm{~Pb} /{ }^{204} \mathrm{~Pb}=15.51 \sim 15.72,{ }^{208} \mathrm{~Pb} /{ }^{204} \mathrm{~Pb}=37.91 \sim 38.59$. As can be seen from Fig.5, constructed from the lead isotope pattern, we could see $\mathrm{Pb}$ isotopic compositions of Qixiashan ores fell among the zone of mantle, orogenic belt and the upper crust growth curve, indicating that the lead isotope had a mixed source of mantle, orogenic belt and the upper crust. As can be seen from Fig.6, in the $\Delta \gamma-$ $\Delta \beta$ genetic classification diagram, samples mainly projected in the zone of the mantle and the crust and upper mantle mixing area, showing mixed genesis of mantle lead and crust lead. It's clear that the mineralization of Qixiashan deposit was obviously affected by magmatism, and magmatism provided a large quantity of material.

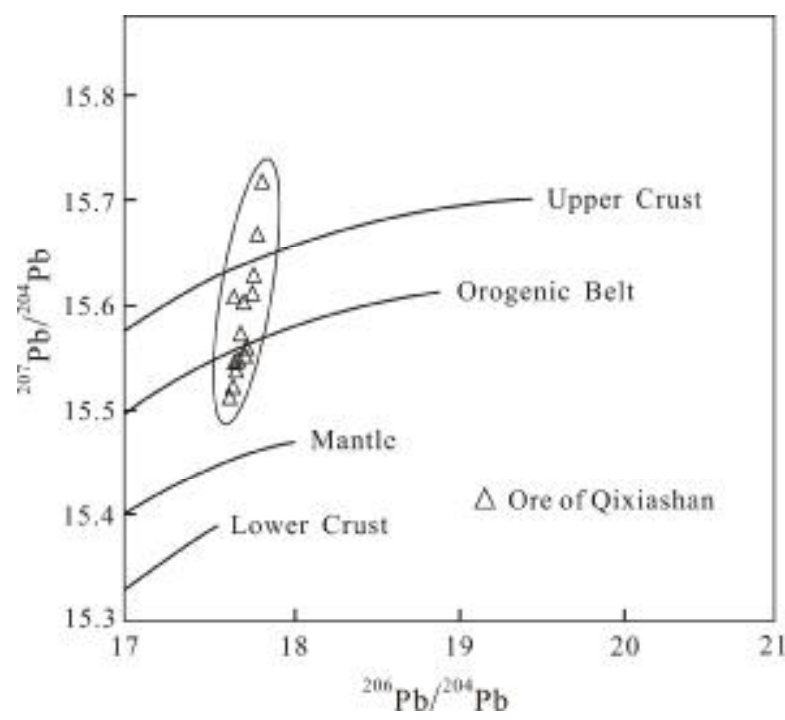

Figure 5. Diagram showing the evolution of tectonic settings for ${ }^{207} \mathrm{~Pb} /{ }^{204} \mathrm{~Pb}-{ }^{206} \mathrm{~Pb} /{ }^{204} \mathrm{~Pb}$ of ore lead isotope from the Qixiashan deposit [23]

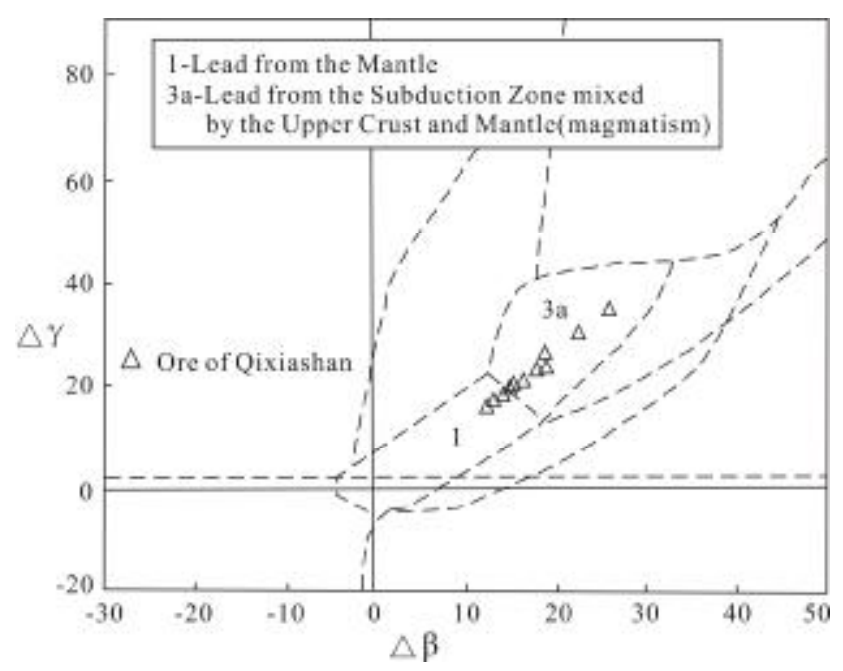

Figure 6. $\Delta \gamma-\Delta \beta$ diagram of genetic classification of ore lead isotopes from the Qixiashan deposit [24]

\section{CONCLUSIONS}

(1) The research of $\mathrm{C}$ and $\mathrm{O}$ isotopes of calcite in Qixiashan deposit indicated that the main source of carbon at main mineralization stage in the deposit was the magma. With the water-rock interaction going on and the addition of meteoric water, isotope exchange occurred, and oreforming fluids changed towards higher $\delta^{13} \mathrm{C}$ and lower $\delta^{18} \mathrm{O}$ direction and finally evolved to the mixing fluid with magmatic water dominated and meteoric water supplemented.

(2) The study on $\mathrm{H}$ and $\mathrm{O}$ isotopes in Qixiashan deposit indicated that the ore-forming fluid at the early stage of mineralization was magmatic water, showing mineralization characteristics of magmatic water mixing with meteoric water with the progress of mineralization going on.

(2) The $\delta^{34} \mathrm{~S}$ values of the sulfur isotope of the ores at the main hydrothermal mineralization in Qixiashan deposit showed a narrow range of $-4.6 \% \sim 3.8 \%$ with a clear distribution of the tower figure, showing that the main source of sulfur was from the mantle at the main 
mineralization stage. In addition, the $\delta^{34} \mathrm{~S}$ values of pyrite with sedimentary characteristic varied from $27.4 \%$ \% $6.9 \%$, indicating the interfusion of depositional sulfur from the surrounding rocks.

(3) Research on lead isotopes of ores in Qixiashan deposit suggested that the source of lead was not simply the crust or mantle, but rather a combination of lead from the upper mantle and crust brought by the magmation.

In conclusion, the metallogenic material of Qixiashan $\mathrm{Pb}-\mathrm{Zn}-\mathrm{Ag}$ polymetallic deposit mainly derived from the magma. Besides providing thermal power for ore solution migrating, the magmatism has also provided the main $\mathrm{Pb}$, $\mathrm{Zn}$ and $\mathrm{Cu}$ metallogenic material. There is also part of the metallogenic material deriving from the underlying Sinian stratum $[8,20]$. These indicate the metallogenic material had a multi-source feature. The ore-forming fluids are dominated by the mixture of magmatic hydrothermal fluid and meteoric water from the later period. The main source of material was magma at early mineralization stage. With the progress of mineralization going on, atmospheric precipitation and dissolution of carbonate mineralization participated in the late mineralization. The deposit was a typical magmatic hydrothermal deposit.

\section{ACKNOWLEDGMENT}

The research work was supported by Geological Survey of China Geological Survey Project Dynamic (12120113090000, 1212011220678 \& 1212011220855).

\section{REFERENCES}

[1] Y.Q. Zhen and J.X. Chen, "Compositions of sulfur and lead isotope and the origin of Qixiashan lead-zine deposit in Nanjing," Journal of Guilin College of Geology, vol. 6, 1986, pp. 319-328.

[2] Y.Z. Yang, "Characteristics and geologic signification of the small amplitude-low gradient magnetic anomaly in Qixiashan polymetallic ore area, Nanjing," Journal of Guilin College of Geology, vol. 9, 1989, pp. 202-208.

[3] C.J. Gui and S. Jing, "Ore-forming properties and prospect of $\mathrm{Pb}-$ Zn polymetallic ore deposit in Xixia Mountain of Nanjing," Journal of Geology, vol. 35, 2011, pp. 395-400, doi:10.3969/ j.issn.16743636.2011 .04 .395

[4] X.S. Guo, Z.M. Xiao, Y.J. Ou and Q.X. Lu, "On the genesis of the Qixiashan lead-zinc ore deposit in Nanjing," Mineral Deposits, vol. 4, 1985, pp. 11-21.

[5] X.S Liu and Z.Q. Chen, "A study of the strata-bound polymetallic pyrite deposit of chishiashan in Nanjing," Journal of Guilin College of Geology, vol. 5, 1985, pp. 121-130.

[6] Q.L. Zhong, "Discovery and Prospecting of Large Scale Qixiashan $\mathrm{Pb}-\mathrm{Zn}$-Ag Polymetallic Deposit in Nanjing," Jiangsu Geology, vol. 22, 1998, pp. 56-61.

[7] G.T. Pan, Q.H. Xiao, S.N. Lu, J.F. Deng, Y.M. Feng, K.X. Zhang, et al., "Subdivision of tectonic units in China," Geology in China, vol.36, 2009, pp. 1-28, doi:10.3969/j.issn.1000-3657.2009.01.001.
[8] Z.F. Xu, Z.H. Zeng, "Discussions on relationship between mineralization and magmatism in Qixiashan $\mathrm{Pb} \mathrm{Zn} \mathrm{Ag}$ ore deposit of Nanjing," Jiangsu Geology, vol. 30, 2006, pp. 177-182, dol:10.3969/j.issn.1674-3636.2006.03.003.

[9] Y.F. Zheng and J.F. Chen, Stable Isotope Geo-chemistry, Beijing: Sci. Press, 2000

[10] Taylor B E, "Magmatic volatiles: Isotope variation of C, H and S," Reviews in Mineralogy and Geochemistry, vol. 16, 1986, pp. 185225.

[11] Veizer J, Holser W T and Wilgus C K, "Correlation of ${ }^{13} \mathrm{C} /{ }^{12} \mathrm{C}$ and ${ }^{34} \mathrm{~S} /{ }^{32} \mathrm{~S}$ secular variation," Geochimica et Cosmochimica Acta, vol. 44, 1980, pp. 579-588.

[12] Ohmoto H, "Systematics of sulfur and carbon isotopes in hydrothermal ore deposit," Economic Geology, vol. 67, 1972, pp. 551-578.

[13] J.M. Liu, J.J. Liu, "Basin Fluid Genetic Model of Sediment-Hosted Micro-Disseminated Gold Deposits in the Gold- Triangle Area Between Guizhou, Guangxi and Yunnan," Acta Mineralogica Sinica, vol. 17, 1997, pp. 448-456.

[14] J.W. Mao, Y. Hao, T.P. Ding, "Mantle Fluids Involved in Metallogenesis of Jiaodong-East Shandong Gold District:Evidence of C, O and H Isotopes," Mineral Deposits, vol. 21, 2002, pp. 121128, doi:10.3969/j.issn.0258-7106.2002.02.004.

[15] J.J. Liu, M.Q. He, Z.M. Li, Y.P. Liu, C.Y. Li, Q. Zhang, et al., "Oxygen and Carbon Isotopic Geochemistry of Baiyangping Silver-Copper Polymetallic Ore Concentration Area in Lanping Basin of Yunnan Province and Its Significance," Mineral Deposits, vol. 23, 2004, pp. 1-10, doi:10.3969/j.issn.0258-7106.2004.01.001.

[16] Zheng Y F, “Carbon-oxygen isotopic covaiations in hydrothermal calcite during degassing of $\mathrm{CO}_{2}$ : A quantitative evaluation and application to the Kushikino gold mining area in Japan," Mineralium Deposits, vol. 25, 1990, pp. 246-250.

[17] Zheng Y F and Hoefs J, "Carbon and oxygen isotopic covaiations in hydrothermal calcites," Mineralium Deposits, vol. 28, 1993, pp. 79-89.

[18] Y.F. Zheng, "Theoretical Modeling of Stable Isotope Systems and Its Applications to Geochemistry of Hydrothermal ore Deposits," Mineral Deposits, vol. 20, 2001, pp. 57-70, doi:10.3969/ j.issn.0258-7106.2001.01.007.

[19] Barnes H L, "Geochemistry of hydrothermal ore deposits," 3rd. New York: John Wiley \& Sons, 1997, 972p.

[20] S.Q. Ye and Z.H. Zeng, "A study on fluid inclusions in Qixiashan leads and zinc ore deposit, Nanjing," Volcano \& Mineral Resources, vlo. 21, 2000, pp. 266-274, doi:10.3969/j.issn.16714814.2000.04.003.

[21] Taylor D A, "The application of oxygen and hydrogen isotope studies to problems of hydrothermal alteration and ore deposition," Econ Geol, vol. 69, 1974, pp. 843-883.

[22] W.Z. Shen, Stable Isotope Geology, Beijing: Atomic Energy Press, 1987.

[23] Zartman E and Doe B R, "Plumbotectonics: The model (in Evolution of the upper mantle)," Tectonophysics, vol. 75, 1981, pp. 135-162.

[24] B.Q. Zhu, X.H. Li and T.M. Dai, Theory and application of isotopic system of Earth Science-on China continental crust mantle evolution, Beijing: $\quad$ Sci. 